\title{
Rejection of Chloropseudomonas ethylica as a Nomina Rejicienda \\ Request for an Opinion
}

\author{
B. H. GRAY \\ Naval Biosciences Laboratory Naval Supply Center Oakland, California 94625
}

The name Chloropseudomonas and the combination Chloropseudomonas ethylica should be declared nomina rejicienda since descriptions of these organisms were based upon mixed cultures.

Chloropseudomonas was originally proposed as the generic name for a motile, green photosynthetic bacillus (1). Cultures of such an organism were described (10-12), and the generic name Chloropseudomonas was validated, with $C$. ethylica as the type species, for this microbe $(6,8)$. However, ambiguities inherent in published descriptions of cultures of $C$. ethylica were noted $(5,12)$. Originally, $C$. ethylica strains $2 \mathrm{~K}$ and $3 \mathrm{~S}$ were nonmotile rods (11). Later the organism was described as being a motile chloropseudomonad $(10,12)$. Although this inconsistency seemed to be resolved in favor of motility, one major anomaly remained. Cell suspensions were described as being green, but individual cells were colorless $(5,9)$.

The above-mentioned discrepancies and other observed anomalies led to further examination of subcultures of $C$. ethylica strain $2 \mathrm{~K}$. All cultures examined were mixtures of at least two microbes, Chlorobium limicola, a nonmotile, photosynthetic rod, and a heterotrophic, non-photosynthetic, flagellated rod (2). The flagellated rod has since been examined and described as a new genus and species, Desulfuromonas acetoxidans (7). C. limicola and $D$. acetoxidans formed a vigorously growing ecosystem in Larsen medium $(2,4,7)$. It was not possible to isolate a motile Chlorobiaceae from any alleged culture of Chloropseudomonas (2). Also, no isolates asserted to be chloropseudomonads have been described since publication of data by Gray et al. (2) concerning cultures alleged to be C. ethylica. Since pure cultures of an organism legitimately described as a chloropseudomonad are not available, the names Chloropseudomonas and $C$. ethylica should be declared nomina rejicienda on the grounds of nomen confusum (3).

\section{LITERATURE CITED}

1. Czurda, V., and E. Maresch. 1937. Beitrag zur Kenntnis der Athiorhodobakterien-Gesellschaften. Arch. Mikrobiol. 8:99-124.

2. Gray, B. H., C. F. Fowler, N. A. Nugent, N. Rigopoulos, and R. C. Fuller. 1973. Reevaluation of Chloropseudomonas ethylica strain 2-K. Int. J. Syst. Bacteriol. 23:256-264.

3. Lapage, S. P., P. H. A. Sneath, E. F. Lessel, V. B. D. Skerman, H. P. R. Seeliger, and W. A. Clark (ed.) 1975. International code of nomenclature of bacteria, p. 43-44. American Society for Microbiology, Washington, D.C.

4. Larsen, H. 1952. On the culture and general physiology of the green sulfur bacteria. J. Bacteriol. 64:187-196.

5. Olson, J. M. 1973. Historical note on Chloropseudomonas ethylica strain 2-K. Int. J. Syst. Bacteriol. 23:265-266.

6. Opinion 44. 1971. Validation of the generic name Chloropseudomonas Czurda and Maresch 1937 and designation of the type species. Int. J. Syst. Bacteriol. 21:109.

7. Pfennig, N., and H. Biebl. 1976. Desulfuromonas acetoxidans gen. nov. and sp. nov., a new anaerobic, sulfur-reducing, acetate-oxidizing bacterium. Arch. Mikrobiol. 110:3-12.

8. Pfennig, N., and H. G. Trüper. 1969. Proposal to declare Rhodopseudomonas palustris and Chloropseudomonas ethylica as nomina conservanda. Int. J. Syst. Bacteriol. 19:153-154.

9. Pfennig, N., and H. G. Trüper. 1974. The phototrophic bacteria, p. 56. In R. E. Buchanan and N. E. Gibbons (ed.), Bergey's manual of determinative bacteriology, 8th ed. The Williams and Wilkins Co., Baltimore.

10. Shaposhnikov, V. V., E. N. Kondrat'eva, and V. D. Fedorov. 1960. A new species of green sulphur bacteria. Nature (London) 187:167-168.

11. Shaposhnikov, V. N., E. N. Kondrat'eva, E. N. Krasil'Nikova, and A. A. Ramenskaya. 1959. Green bacteria utilizing organic compounds. Dokl. Akad. Nauk. SSSR 129:1424-1426.

12. Skalinskii, E. I., and E. N. Kondrat'eva. 1961. A new species of green sulfur bacteria. Dokl. Akad. Nauk. SSSR 138:456-457. 